\title{
Evaluation of Mycobacterium avium subsp. paratuberculosis faecal culture protocols and media ${ }^{1}$
}

\author{
Paula Ristow²", Marlei Gomes Silva ${ }^{2}$, Leila de Souza Fonseca ${ }^{2}$ and \\ Walter Lilenbaum ${ }^{3}$
}

\begin{abstract}
Ristow P., Silva M.G., Fonseca L.S. \& Lilenbaum W. 2006. [Evaluation of Mycobacterium avium subsp. paratuberculosis faecal culture protocols and media.] Pesquisa Veterinária Brasileira 26(1):1-4. Mycobacteria Laboratory, Centro de Ciências da Saúde, Universidade Federal do Rio de Janeiro, Cidade Universitária, Rio de Janeiro, RJ 21941-590, Brazil. E-mail: paularistow@bigfoot.com

Paratuberculosis is an important enteritis of ruminants caused by Mycobacterium avium subsp. paratuberculosis (Map). The disease is officially considered exotic in Brazil, but recent serological surveys and the isolation of the agent suggest it may occur in our herds. The aim of this study was to evaluate three different formulations of Herrold's egg yolk agar with mycobactin J (HEYM) and four faecal culture protocols considering their ability for Map growth as well as cost and ease of application. Three formulations of HEYM were inoculated with two suspensions of Map. Spiked faeces and naturally contaminated faecal samples were treated by the four faecal culture protocols. Centrifugation protocol and HEYM recommended by OIE showed the best results on the recovery of Map.
\end{abstract}

INDEX TERMS: Paratuberculosis, bovine, diagnosis, mycobacterium.

RESUMO.- [Avaliação de protocolos de cultivo fecal e meios para a cultura de Mycobacterium avium subsp. paratuberculosis.] A paratuberculose é uma importante enterite de ruminantes causada por Mycobacterium avium subsp. paratuberculosis (Map). A enfermidade é oficialmente considerada exótica no Brasil, mas inquéritos sorológicos recentes e o isolamento do agente etiológico sugerem que ela pode estar presente em nossos rebanhos. O objetivo do estudo foi avaliar três diferentes fórmulas do Ágar gema de ovo de Herrold suplementado com micobactina J (HEYM) e quatro protocolos de cultura fecal quanto ao crescimento de Map, bem como custo e facilidade de implementação. Três fórmulas de HEYM foram inoculadas com duas suspensões de Map. Fezes contaminadas artificialmente e naturalmente com Map foram tratadas pelos quatro protocolos de cultura fecal. O protocolo da centrifugação e a fórmula de HEYM recomendada pela OIE

\footnotetext{
${ }^{1}$ Received on February 18, 2005.

Accepted for publication on July 8, 2005.

${ }^{2}$ Mycobacteria Laboratory, Centro de Ciências da Saúde, Universidade Federal do Rio de Janeiro, Cidade Universitária, Rio de Janeiro, RJ 21941590, Brazil. "Author for correspondence. E-mail: paularistow@bigfoot.com

${ }^{3}$ Veterinary Bacteriology Laboratory, Instituto Biomédico, Universidade Federal Fluminense, Niterói, RJ 24210-130, Brazil.
}

demonstraram os melhores resultados quanto à recuperação de Map.

TERMOS DE INDEXAÇÃO: Paratuberculose, bovinos, diagnóstico, mycobacterium.

\section{INTRODUCTION}

Paratuberculosis is a fatal chronic granulomatous enteritis caused by Mycobacterium avium subsp. paratuberculosis (Map) that affects ruminants. It occurs throughout the world and causes serious economic losses (Chiodini et al. 1984). The disease is considered rare and exotic in Brazil and was reported only sporadically, in cases evolving imported animals (Dacorso Filho et al. 1960, Driemeier et al. 1999). Nevertheless, recent serological surveys (Fonseca et al. 2000, Ferreira et al. 2001) and the isolation of the agent (Dias et al. 2002, Ristow et al. 2004) suggest the disease may be present on Brazilian herds.

The isolation of the agent from faeces or tissues is the goldstandard diagnostic method (Stabel 1997), but due to a lack of qualification of veterinary bacteriology laboratories on mycobacteriology and to difficulties inherent to Map's cultivation, it is infrequently performed in Brazil. Map's culture is very slow, takes 8-16 weeks of incubation and is mycobactin dependent (Whipple et al. 1991). Cetylpyridinium chloride (HPC) is the most commonly employed decontaminant for Map culture 
and many protocols using it were proposed (Stabel et al. 2002), including some with two decontamination steps (Whitlock \& Rosenberger 1990). Besides the decontamination steps, culture protocols include the concentration of specimens by sedimentation (Whipple et al. 1991) and/or centrifugation (Whitlock \& Rosenberger 1990, Stabel 1997). Although centrifugation increases contamination (Stabel 1997), it increases culture sensitivity nearly three-fold (Whitlock \& Rosenberger 1990). Several culture media can be used for Map's cultivation like the modified Dubos's, Middlebrook 7H9, 7H10, 7H11, 7H12 Bactec and Löwenstein-Jensen, all supplemented with mycobactin (World Organization for Animal Health 2004), but the most widely used is the Herrold's egg yolk agar supplemented with mycobactin $\mathrm{J}$ (HEYM). The incorporation of antibiotics to media is opportune to control the growth of contaminants (Stabel et al. 2002).

Beyond the inherent difficulty on the cultivation of Map, there is no consensus about HEYM's in house formulations and faecal culture protocols in the literature (Whipple et al. 1991). Although HEYM is commercially available, its cost and import difficulties may limit its use in Brazilian laboratories. The purpose of this work was to evaluate three different formulations of HEYM and four faecal culture protocols, considering their ability for Map growth as well as cost and ease of application. Paratuberculosis should be considered a sanitary threat in Brazil and due to our important beef and dairy industries, it is utterly necessary to prevent and control it. This study will probably contribute to the bacteriological diagnosis of paratuberculosis in Brazil.

\section{MATERIALS AND METHODS}

\section{HEYM's evaluation}

Three Herrold's egg yolk agar formulations supplemented with mycobactin J (Allied Monitor, USA) were evaluated. Formulations were prepared as described below. HEYM named HEYM-OIE is recommended by the World Organization for Animal Health (2004) and was processed following OIE standards, adjusting the $\mathrm{pH}$ of the liquid medium to 7.0 and autoclaving it at $121^{\circ} \mathrm{C}$ for 25 minutes. HEYM named HEYM-W is recommended by Whipple et al. (1991) and was processed as HEYM-OIE, adjusting the $\mathrm{pH}$ of the suspension prior to autoclaving to 8.1-8.4. Addition of amphotericin $\mathrm{B}$, as recommended by the authors, was not employed. HEYM named HEYM-P was processed as HEYM-OIE, adding $6.25 \mathrm{~g}$ of sodium pyruvate. The $\mathrm{pH}$ of the liquid medium was adjusted to 7.5 and it was autoclaved at $121^{\circ} \mathrm{C}$ for $20 \mathrm{~min}$. Fresh eggs from a flock that does not receive antibiotics were used in all media formulations. Following quality control procedures for HEYM (Whipple et al. 1991), all slopes were incubated at $37^{\circ} \mathrm{C}$ for $48 \mathrm{~h}$ and $10 \%$ of those for seven days before use to check sterility.

To access the ability for Map growth of each of HEYM formulations, a field strain (Malele 734 - RFLP standard A) isolated from a clinical case of bovine paratuberculosis in Argentina (Moreira et al. 1999) grown in HEYM - OIE formulation was used. A Mc Farland number one suspension, containing approximately $10^{7} \mathrm{Map} \mathrm{cfu} \mathrm{mL}^{-1}$, was prepared in sterile distilled water by vortexing colonies on a tube with sterile glass beads. Successive dilutions were prepared in sterile distilled water. Following the recommendations of Whipple et al. (1991), $0.1 \mathrm{~mL}$ of two light bacterial suspensions containing approximately $10^{3}$ and $10^{2}$ Map cfu mL ${ }^{-1}$ were inoculated in duplicate on HEYM's slopes of each formulation. Tubes were incubated at $37^{\circ} \mathrm{C}$ and observed in two weeks intervals until 16 weeks for bacterial growth.

\section{Culture protocols evaluation}

Evaluation of faecal culture protocols was done with artificially spiked faeces, artificially spiked water and naturally infected faeces. Faeces were collected for the spiking with Map was from a healthy, serologically and culture negative bull, from a paratuberculosis-free beef herd. Naturally infected faecal samples were collected from four cows with positive faecal culture (identified as 103, 120, Jacuba and Humorista) obtained from a paratuberculosis-positive dairy herd in Rio de Janeiro, Brazil (Ristow et al. 2004). Two of them (Jacuba and Humorista) were from high shedder cows with characteristic clinical symptoms and the other two (numbers 103 and 120), from clinically asymptomatic medium shedder cows.

Spiking of faeces. A Mc Farland number one suspension of Map was prepared as described above. Successive dilutions were prepared in sterile distilled water. Suspensions containing approximately $10^{5}$, $10^{4}$ and $10^{3} \mathrm{Map} \mathrm{cfu} \mathrm{ml}^{-1}$ were prepared, attempting to reproduce high, medium and low shedding conditions, as usually observed in infected herds. Spiking was prepared adding one $\mathrm{ml}$ of each suspension to one gram of faeces, so that there were approximately $5.0 \times 10^{4}$; $5.0 \times 10^{3}$ and $5.0 \times 10^{2} \mathrm{Map}$ cfu $\mathrm{g}$ faeces ${ }^{-1}$. Samples were homogenized in $50 \mathrm{ml}$ plastic tubes with glass beads on vortex for one min and processed by the four culture protocols. As a recovery control, distilled water was spiked by the same procedure.

Culture protocols. a) Sedimentation was performed as described by the World Organization for Animal Health (2004). Briefly, one gram of faeces was added to $20 \mathrm{ml}$ of sterile distilled water, tubes were shaken for $30 \mathrm{~min}$ and then allowed to stand undisturbed for $30 \mathrm{~min}$. Five $\mathrm{ml}$ of the supernatant were added to $0.75 \% \mathrm{HPC}$ (Sigma, USA). Tubes were inverted several times and allowed to stand undisturbed for 18 hours at room temperature for decontamination. HEYM slopes were inoculated with $0.1 \mathrm{ml}$ of the undisturbed sediment.

b) Centrifugation was performed as described by Stabel (1997), with brief modifications. Until the decontamination stage it was performed consistently like the sedimentation protocol, employing $25 \mathrm{ml}$ of $0.9 \% \mathrm{HPC}$ overnight. Tubes were centrifuged at $1700 \times \mathrm{g}$ for $20 \mathrm{~min}$, the supernatant was decanted and the pellet was resuspended in $1 \mathrm{ml}$ of $50 \mu \mathrm{g} / \mathrm{ml}$ amphotericin B (Bristol Meyers Squibb, Brazil). HEYM slopes were inoculated with $0.2 \mathrm{ml}$ of the suspension.

c) Double incubation was performed as described by Whitlock \& Rosenberger (1990), with brief modifications. Two grams of faeces were added to $35 \mathrm{ml}$ of sterile distilled water with sterile glass beads, tubes were shaken for $30 \mathrm{~min}$ and then allowed to stand undisturbed for $30 \mathrm{~min}$. Five $\mathrm{ml}$ of the supernatant were added to a decontaminant mixture containing $25 \mathrm{ml}$ of $0.9 \% \mathrm{HPC}$ and $30 \mathrm{ml}$ of BHI and the samples were allowed to decontaminate overnight at $37^{\circ} \mathrm{C}$. Samples were centrifuged at $900 \times \mathrm{g}$ for $30 \mathrm{~min}$ and the supernatant discarded. Pellets were resuspended in $1 \mathrm{ml}$ of antibiotic brew containing 50\% BHI broth with $100 \mu \mathrm{g} / \mathrm{ml}$ vancomicin (Elly Lily, Brazil); $100 \mu \mathrm{g} / \mathrm{ml}$ nalidixic acid (Merck, Germany) and $50 \mu \mathrm{g} / \mathrm{ml}$ amphotericin B. Tubes were vortexed and incubated overnight at $37^{\circ} \mathrm{C}$. HEYM slopes were inoculated with $0.25 \mathrm{ml}$ of the suspension.

d) Double centrifugation/decontamination or NADC (National Animal Disease Center) was performed as described by Stabel (1997). Until the settling of particles for $30 \mathrm{~min}$ it was performed consistently like the double incubation protocol. Then, the entire supernatant fraction was centrifuged at $1700 \times \mathrm{g}$ for $20 \mathrm{~min}$, the supernatant discarded and the pellets resuspended in $30 \mathrm{~mL} 0.9 \% \mathrm{HPC} / \mathrm{BHI}$ solution. After overnight decontamination at $37^{\circ} \mathrm{C}$, samples were centrifuged at $1700 \times \mathrm{g}$ for $20 \mathrm{~min}$ and the supernatant discarded. Pellets were resuspended in $1 \mathrm{ml}$ of antibiotic solution containing $100 \mu \mathrm{g} / \mathrm{ml}$ vancomicin, $100 \mu \mathrm{g} / \mathrm{ml}$ nalidixic acid and $50 \mu \mathrm{g} / \mathrm{mL}$ amphotericin B. 
Tubes were incubated overnight at $37^{\circ} \mathrm{C}$ and HEYM slopes were inoculated with $0.2 \mathrm{ml}$ of the suspension.

Each sample was cultivated in duplicate on HEYM slopes (OIE formulation) with and without antibiotics $(50 \mu \mathrm{g} / \mathrm{ml}$ nalidixic acid, $50 \mu \mathrm{g} /$ $\mathrm{ml}$ amphotericin B and $50 \mu \mathrm{g} / \mathrm{ml}$ vancomicin), totalling four HEYM slopes per sample. Antibiotic solutions were prepared according to the fabricants instructions and were filtered on Millipore membranes $(0.22 \mu \mathrm{m})$. Tubes were incubated at $37^{\circ} \mathrm{C}$ and observed in a two weeksinterval for 16 weeks and the colonies enumerated.

\section{Statistical analysis}

Student's $T$ test and Group Analysis of Variance (ANOVA) were employed to analyze the colony counts.

\section{RESULTS AND DISCUSSION}

The growth time of Map in the three different HEYM formulations was 60 days and no contamination was observed on the tubes. When suspension $10^{3}$ was used, a mean of 435.0 ( \pm 15.0 ) colonies was observed in HEYM-OIE; 250.0 ( \pm 50.0 ) in HEYM-W and $137.0( \pm 7.0)$ in HEYM-P. Statistics showed significant difference between HEYM-OIE and HEYM-W ( $p=0.003)$, but not between HEYM-OIE and HEYM-P $(p=0.071)$ or HEYM-P and HEYM-W $(\mathrm{p}=0.155)$. With suspension $10^{2}$, a mean of $50.0( \pm 3.0)$ colonies in HEYM-OIE, 5.0 ( \pm 2.0 ) in HEYM-W and 19.5 colonies $( \pm 1.5)$ in HEYM-P was observed. HEYM-OIE was ten-fold more sensitive on the colony detection than HEYM-W $(p=0.06)$ and 2.5-fold more sensitive than HEYM-P $(p=0.012)$. HEYM-OIE was considered the most appropriate for Map culture and from then on has been adopted in our laboratory as the routine medium. Beyond being recommended by the World Organization for Animal Health (2004), this formula is also used by many authors (Whitlock \& Rosenberger 1990; Stabel 1997).

The highest recovery of Map on spiked samples was on the centrifugation protocol, with a mean of $44.5 \mathrm{CFU} / \mathrm{slope}$ (Table 1). The double incubation protocol recovered $30.6 \mathrm{CFU} /$ slope, followed by NADC (26.2 CFU/slope) and sedimentation (14.3 $\mathrm{CFU} /$ slope). There was no contamination on spiked samples processed by sedimentation, double incubation or NADC protocols, but when centrifugation protocol was used, one HEYM slope without antibiotics presented contamination on sample faeces $/ 10^{3}(4.2 \%)$. The growth of Map was faster (30

Table 1 . Mean recovery of Map (CFU per HEYM tube) on the four culture protocols per sample on spiked samples

\begin{tabular}{lcccc}
\hline \multirow{2}{*}{$\begin{array}{c}\text { Sample/ } \\
\text { suspension }\end{array}$} & \multicolumn{4}{c}{ CFU per HEYM tube on protocols } \\
\cline { 2 - 5 } & $\begin{array}{c}\text { Sedimen- } \\
\text { tation }\end{array}$ & $\begin{array}{c}\text { Centrifu- } \\
\text { gation }\end{array}$ & $\begin{array}{c}\text { Double } \\
\text { incubation }\end{array}$ & NADC \\
\hline Water $/ 10^{5}$ & 10.5 & 87.5 & 58.5 & 0.5 \\
Water $/ 10^{4}$ & 1.75 & 8.75 & 7.25 & 0 \\
Water $/ 10^{3}$ & 0 & 1.5 & 0.25 & 0 \\
Faeces $/ 10^{5}$ & 66.25 & 100 & 90 & 100 \\
Faeces $/ 10^{4}$ & 5.75 & 61.25 & 26.5 & 55 \\
Faeces $/ 10^{3}$ & 1.5 & 8 & 1 & 1.5 \\
Mean total recovery & $343 / 24$ & $1068 / 24$ & $734 / 24$ & $629 / 24$ \\
& 14.3 & 44.5 & 30.6 & 26.2
\end{tabular}

\footnotetext{
a per protocol, obtained by the mean on the 24 four inoculated tubes.
}

days) in the centrifugation and NADC protocols, indicating a better sensitivity of those protocols.

On naturally infected faeces, the highest recovery of the bacterium was also obtained with the centrifugation protocol, with a mean of $42.7 \mathrm{CFU} /$ slope and $25 \%$ of contamination. NADC protocol recovered $20.3 \mathrm{CFU} /$ slope with a contamination rate of $31.2 \%$; followed by double incubation protocol, with $13.3 \mathrm{CFU} /$ slope and contamination rate of $25 \%$ and sedimentation, with $3.9 \mathrm{CFU} /$ slope and a contamination rate of $6.2 \%$. Despite all protocols were able to recover Map from the two high shedders' samples (Jacuba and Humorista), none of them recovered bacteria from the two medium shedders' samples (numbers 103 and 120). There was high contamination (40.6\%) on slopes of samples 103 and 120 , what could explain the absence of growth. The low sensitivity of Map culture could also be responsible for not recovering Map from samples 103 and 120 (Stabel 1997).

As to the decontamination ability of each protocol, on both naturally infected and spiked samples, centrifugation and NADC protocols showed the greatest number of contaminations (12.5\%), followed by double incubation protocol (10\%) and sedimentation (1.6\%). A high contamination level using the centrifugation protocol was previously described by Stabel (1997), yet minimal contamination was observed when the NADC method was used. Eamens et al. (2000) observed no contamination using the sedimentation protocol, what agrees with the results found in this study; nevertheless, for the double incubation protocol the contamination rate observed was $0.6 \%$. It is important to observe that contamination was only observed on HEYM slopes with no antibiotics. This is a very useful finding and endorses the necessity of inclusion of antibiotics in media when processing faecal samples, which agrees with the recommendation of Stabel et al. (2002).

Comparison between the culture protocols is hindered due to the different characteristics of the protocols. The amount of faeces used on the double incubation and NADC protocols $(2 \mathrm{~g})$ is bigger than the amount used on the sedimentation and centrifugation protocols $(1 \mathrm{~g})$ and furthermore, different amounts of inoculum were seeded onto HEYM slopes for the different protocols: $0.1 \mathrm{ml}$ for sedimentation, $0.2 \mathrm{ml}$ for centrifugation and $\mathrm{NADC}$ and $0.25 \mathrm{ml}$ for double incubation.

This study evaluated four culture protocols and three different HEYM formulations. It permitted us to choose the centrifugation protocol with inoculation on HEYM- OIE formula with and without antibiotics as a routine procedure for the cultivation of faeces for Mycobacteruium avium subsp. paratuberculosis. The centrifugation protocol presented the most satisfactory recovery of Map and the contamination of slopes was avoided by the addition of antibiotics to media. It is also less labour-intensive, faster and less expensive when compared to the double incubation and NADC protocols, which are major advantages when processing larger number of faecal samples.

Acknowledgements.- This study was supported by CAPES, CNPq and FAPERJ We are thankful to Prof. F. Paolicchi for providing the Mycobacterium avium subsp. paratuberculosis strain; to Prof. F. P. Camara for the statistical analysis, to Prof. R. Ferreira and to Laboratories Elli Lilly do Brasil and Bristol Meyers Squibb Brasil for providing Vancomycin and Amphotericin B, respectively. 


\section{REFERENCES}

Chiodini R.J., van Kruiningen H.J. \& Merkal R. 1984. Ruminant Paratuberculosis (Johne's disease): the current status \& future prospects. Cornell Vet. 74:218-262.

Dacorso Filho P., Campos I.O.N., Faria J.F. \& Langenegger J. 1960. Doença de Johne (Paratuberculose) em bovinos nacionais. Arqs Inst. Biol. Animal, Rio de J., 3:129-139.

Dias L.D., Lobato P.M.P.C., Lage A.P., Assis R.A. \& Santos T.M. 2002. Isolamento do Mycobacterium paratuberculosis a partir de fezes de bovinos suspeitos de paratuberculose. Anais XXIX Congr. Bras. Med. Veterinária, Gramado, RS.

Driemeier D., Cruz C.E.F., Gomes M.J.P., Corbellini L.G., Loretti A.P. \& Colodel E.M. 1999. Aspectos clínicos e patológicos da paratuberculose em bovinos no Rio Grande do Sul. Pesq. Vet. Bras. 19:109-115.

Eamens G.J., Whittington R.J., Marsh I.B., Turner M.J., Saunders V., Kemsley P.D. \& Rayward D. 2000. Comparative sensitivity of various faecal culture methods \& ELISA in dairy cattle herds with endemic Johne's disease. Vet. Microbiol. 77:357-367.

Ferreira R., Fonseca L.S. \& Lilenbaum W. 2001. Detecção de anticorpos contra Mycobacterium paratuberculosis em rebanhos bovinos do Estado do Rio de Janeiro, Brasil. Revta Bras. Med. Vet. 23:19-24.

Fonseca L.F.L., Olival A., Pereira C.C., Heinemann M.B. \& Richtzenhain L.J. 2000. Identificação de anticorpos anti-Mycobacterium paratuberculosis em rebanhos leiteiros do Estado de São Paulo. Arq. Fac. Vet., UFRGS, 28:51 60.
Moreira A.R., Paolicchi F., Morsella C., Zumarraga M., Cataldi A., Fabiana B., Alicia A., Piet O., van Soolingen D. \& Romano M. I. 1999. Distribution of IS900 restriction fragment length polymorphism types among animal Mycobacterium avium subsp. paratuberculosis isolates from Argentina \& Europe. Vet. Microbiol. 70:251-259.

Ristow P., Marassi C.D., Rodrigues A.B.F., Oelemann W.M.R., Rocha F., Santos A.S.O., Carvalho E.C.Q., Carvalho C.B., Ferreira R., Fonseca L.S. \& Lilenbaum W. 2004. Investigation of Bovine Paratuberculosis on a Brazilian Dairy Herd through Serological, Bacteriological, Molecular \& Anatomopathological tools. Anais XVII Congr. Latinoamericano e X Congr. Argentino de Microbiologia, Buenos Aires.

Stabel J.R. 1997. An improved method for cultivation of Mycobacterium paratuberculosis from bovine faecal samples \& comparison to three other methods. J. Vet. Diag. Invest. 9:375-380.

Stabel J.R., Wells S.J. \& Wagner B.A. 2002. Relationships between faecal culture, ELISA, \& bulk tank milk test results for Johne's disease in US dairy herds. J. Dairy Sci. 85:525-531.

Whipple D.L., Callihan D.R. \& Jarnagin J.L. 1991. Cultivation of Mycobacterium paratuberculosis from bovine faecal specimens $\&$ a suggested standardized procedure. J. Vet. Diag. Invest. 3:368-373.

Whitlock R.H. \& Rosenberger A.E. 1990. Faecal culture protocol for Mycobacterium paratuberculosis a recommended procedure. In: Proc. Annual Meeting U.S. Animal Health Association 94:280-285.

World Organization for Animal Health 2004. Manual of Diagnostic Tests \& Vaccines for Terrestrial Animals. Part 2, Section 2.2, Chapter 2.2.6. http:/ /www.oie.int/eng/normes/mmanual/A_00045.htm. 